\title{
DISEMINASI TEKNOLOGI PEMBUATAN PESTISIDA BOTANI NERIUM OLEANDER LINN. UNTUK PENGENDALIAN HAMA TANAMAN SAYURAN
}

\author{
Burhanuddin Haji Nasir ${ }^{1)^{*}}$, Moh. Hibban Toana ${ }^{1)}$, Usman Made ${ }^{1)}$ Sri Anjar Lasmini', \\ Nur Hayati' ${ }^{1)}$ Idham $^{1)}$ Moh. Syahrul Asdar ${ }^{2)}$, Idul Fuqra ${ }^{3)}$ \\ ${ }^{1)}$ Program Studi Agroteknologi Fakultas Pertanian Universitas Tadulako \\ ${ }^{2)}$ Mahasiswa BKU Proteksi Program Studi Agroteknologi Fakultas Pertanian Universitas Tadulako \\ ${ }^{3)}$ Mahasiswa BKU Agronomi Program Studi Agroteknologi Fakultas Pertanian Universitas Tadulako \\ *Email: burhajinasir@gmail.com; moh.hibbantoana@gmail.com; usmanmade.atjong@gmail.com; \\ lasminisrianjar@gmail.com; nurhayatirs939@gmail.com; idhamfaperta@gmail.com;
}

\begin{abstract}
Abstrak
Desa Sidera termasuk salah satu daerah penghasil tanaman sayuran di Kabupaten Sigi yang turut mensuplai kebutuhan masyarakat perkotaan di Palu. Desa Sidera yang sebelumnya dikenal dengan Unit Permukiman Transmigrasi Sidera memiliki lahan 250 ha sebagai areal penanaman sayuran. Kendala yang dihadapi oleh petani di desa tersebut adalah adanya serangan hama dan penyakit sehingga produksi sering mengalami kegagalan. Untuk mengatasi hal tersebut program pengabdian desiminasi hasil penelitian menawarkan paket teknologi budidaya yang berorientasi pada peningkatan produktivitas antara lain dengan mengusahakan sarana dan prasarana produksi berbasis kearifan lokal. Program pengabdian diseminasi hasil penelitian ini bertujuan untuk melakukan desiminasi, pembinaan dan pemberdayaan kepada masyarakat dalam mengembangkan ekstrak daun tumbuhan Nerium oleander sebagai pestisida botani/nabati. Target khusus yang ingin dicapai adalah meningkatkan kemampuan dan ketrampilan masyarakat dalam menyiapkan sarana pertanian melalui pembuatan dan pengembangan pestisida botani berbasis kearifan lokal. Metode yang diterapkan adalah: pelatihan, demonstrasi dan demplot teknologi, pendampingan serta pembinaan yang dilakukan secara partisipatif. Hasil pelaksanaan program menunjukkan bahwa peserta kegiatan dapat menerima teknologi tersebut dan mengembangkan di lahan usaha taninya.
\end{abstract}

Kata Kunci : Ekstrak tumbuhan Nerium oleander, pestisida botani, sarana dan prasarana pertanian

\section{PENDAHULUAN}

Luas lahan usahatani di Desa Sidera mencapai 250 ha dengan jumlah penduduk sebanyak 2.444 jiwa (BPS Kecamatan Sigi Dalam Angka, 2017). Kepemilikan lahan setiap kepala keluarga petani antara 0,25 ha dan 0,5 ha dengan luas areal lahan rata-rata 0,32 ha. Sebagian besar petani di desa tersebut hanya menggantungkan hidupnya dari hasil tani. Petani merasakan kesulitan hidup, jika tanamannya tidak menghasilkan karena berbagai faktor terutama bila diserang oleh hama dan penyakit. Demikian pula terkadang produksinya menurun yang disebabkan karena iklim yang tidak bersahabat dan kekurangan hara.

Budidaya sayur-sayuran merupakan salah satu peluang bisnis bagi petani sesuai potensi dan sumberdaya yang tersedia, karena komoditi sayursayuran dapat diusahakan dan dilakukan oleh 
sebagian besar rumah tangga petani, baik untuk konsumsi keluarga maupun untuk dijual. Kondisi riil di Kecamatan Sigi Biromaru menunjukkan bahwa lingkungan alam dengan geografisnya agak berbukit, dengan cuaca dan potensi lahan yang cukup mendukung bagi pengembangan usaha tani sayur-sayuran.

Praktek budidaya sayur-sayuran di Desa Sidera Kecamatan Sigi Biromaru dilakukan dengan tujuan untuk meningkatkan pendapatan petani, namun hal tersebut tidak dapat tercapai secara optimal karena berbagai penyebab. Penyebab utama yang dihadapi oleh petani didalam menjalankan kegiatan usahataninya adalah serangan hama dan penyakit yang seringkali mengakibatkan kegagalan panen.

Petani umumnya menggunakan pestisida sintetik untuk mengendalikan hama dan penyakit yang menyerang tanaman budidayanya karena cara kerja yang cepat dan ampuh. Penggunaan insektisida sintetis yang dilakukan oleh petani biasanya 2-3 hari sekali, bahkan petani mencampur beberapa jenis pestisida dalam satu kali aplikasi (Ahmad et al., 2018). Teknik tersebut walaupun mampu menekan serangan hama namun tanpa disadari terdapat bahaya besar yang mengancam. Saat ini kita dapat melihat dan merasakan dampak negatif penggunaan pestisida seperti terbunuhnya organisme yang menguntungkan bagi tanah dan tanaman, resistensi dan resurgensi pada OPT, keracunan pada pekerja di lapangan serta pencemaran pada tanah, air, udara, dan produk yang dihasilkan (Astuti et al., 2013; Wang et al., 2018). Selain itu juga mengakibatkan hilangnya kesempatan bagi petani untuk menangkap peluang imbalan ekonomi yang lebih tinggi.

Untuk mengurangi dampak negatif dari penggunaan pestisida sintetis dapat dilakukan dengan penggunaan bahan alam sebagai bahan pengendali hama ramah lingkungan. Tanaman yang memiliki potensi sebagai insektisida botani / nabati yaitu bunga mentega Nerium oleander Linn (Gambar 1). Tanaman tersebut berpotensi sebagai larvasida nabati karena bersifat toksik. $N$. oleander banyak dijumpai di Sulawesi Tengah sebagai tanaman hias di pekarangan rumah maupun di pinggir jalan.
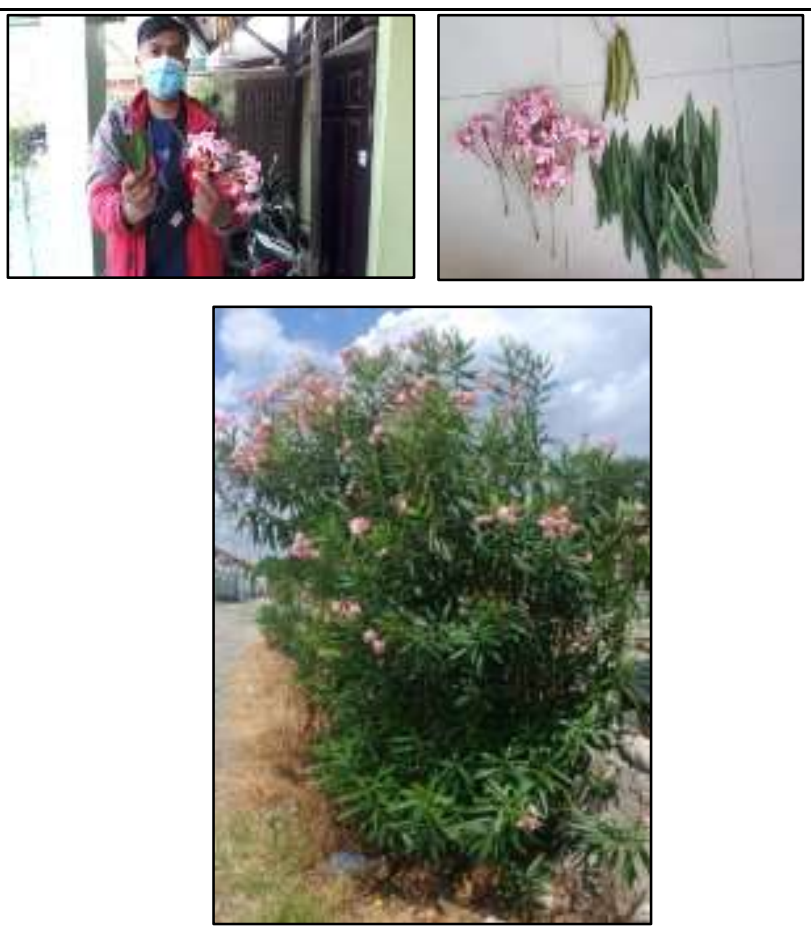

Gambar 1. Tumbuhan Nerium Oleander

Bagian tanaman $N$. oleander yang dapat digunakan sebagai insektisida botani adalah akar, batang, kulit batang, daun dan bunga, tetapi yang paling sering digunakan adalah daunnya karena paling banyak mengandung oleandrin. Zat tersebut bekerja sebagai racun perut dan penghambat daya makan larva. Racun perut akan mempengaruhi metabolisme larva setelah memakan racun, kemudian racun akan masuk ke dalam tubuh dan dicerna dalam saluran tengah yang setelah diedarkan bersama cairan yang fungsinya seperti darah. Racun yang terbawa cairan tersebut akan mempengaruhi sistem saraf larva dan kemudian akan menimbulkan kematian (Wahyudi, 2010).

Hasil penelitian Nasir et al. (2020) menunjukkan bahwa konsentrasi ekstrak 43 g/L efektif dalam mengurangi padat populasi dan intensitas serangan larva Spodoptera exigua pada tanaman bawang merah. Dari hasil penelitian tersebut maka perlu terus digalakkan penggunaannya pada tanaman sayuran lainnya agar penggunaan pestisida kimia dapat dikurangi untuk mendukung sistem pertanian berkelanjutan. 
Petani di Desa Sidera belum memanfaatkan ekstrak N. oleander sebagai bahan pengendali hama karena belum mengetahui manfaat dan cara pembuatannya, pada hal potensi $N$. oleander tersebut sangat besar karena banyak tumbuh di sekitar halaman rumah masyarakat.

Program pengabdian diseminasi hasil penelitian bertujuan untuk memasyarakatkan penggunaan ekstrak tumbuhan $N$. oleander sebagai pestisida botani / nabati ramah lingkungan untuk mengurangi penggunaan insektisida kimia sintetis supaya produk hasil pertanian lebih sehat untuk dikonsumsi dan memiliki nilai jual yang tinggi agar pendapatan petani meningkat.

\section{METODE}

\section{Metode pendekatan yang ditawarkan}

Metode yang digunakan adalah ceramah dan diskusi kelompok menggunakan prinsip pembelajaran orang dewasa, serta demonstrasi dan praktek yang dilakukan secara partisipatif.

\section{Tahapan pelaksanaan kegiatan}

Program pengabdian diseminasi hasil penelitian dilaksanakan pada kelompok tani "Tani Maju" dengan jumlah anggota 20 orang dengan tahapan sebagai berikut:

Tabel 1. Tahapan pelaksanaan program pengabdian diseminasi hasil penelitian

\begin{tabular}{|c|l|l|}
\hline Uraian Kegiatan & \multicolumn{1}{|c|}{ Tujuan } & \multicolumn{1}{c|}{ Sasaran } \\
\hline 1. Sosialisasi & $\begin{array}{l}\text { Untuk } \\
\text { memberikan } \\
\text { informasi yang } \\
\text { berhubungan } \\
\text { dengan kegiatan } \\
\text { program } \\
\text { diseminasi hasil } \\
\text { penelitian }\end{array}$ & $\begin{array}{l}\text { Instansi } \\
\text { terkait, } \\
\text { masyarakat } \\
\text { lokal dan } \\
\text { lembaga adat }\end{array}$ \\
& $\begin{array}{l}\text { Untuk } \\
\text { memberikan }\end{array}$ & $\begin{array}{l}\text { Kelompok } \\
\text { tani mitra, } \\
\text { lembaga adat } \\
\text { 2. Penyuluhan / } \\
\text { pelatihan }\end{array}$ \\
& $\begin{array}{l}\text { tambahan } \\
\text { pengetahuan } \\
\text { kepada }\end{array}$ \\
masyarakat & masyarakat \\
& lokal \\
& sasaran & \\
\hline $\begin{array}{c}\text { 3. Kerja praktek } \\
\text { (rancang bangun }\end{array}$ & $\begin{array}{l}\text { Untuk } \\
\text { memperkenalkan }\end{array}$ & $\begin{array}{l}\text { Kelompok } \\
\text { tani mitra }\end{array}$ \\
\hline
\end{tabular}

\begin{tabular}{|l|l|l|}
\hline teknologi) & $\begin{array}{l}\text { teknologi yang } \\
\text { akan } \\
\text { diaplikasikan } \\
\text { pada kegiatan } \\
\text { usaha taninya }\end{array}$ & \\
\hline 4. Pendampingan & $\begin{array}{l}\text { Untuk } \\
\text { memudahkan } \\
\text { transfer teknologi } \\
\text { kepada kelompok }\end{array}$ & $\begin{array}{l}\text { Kelompok } \\
\text { tani mitra }\end{array}$ \\
& $\begin{array}{l}\text { sasaran yang } \\
\text { diberikan melalui }\end{array}$ & \\
& Program & \\
& pengabdian & \\
diseminasi hasil & \\
penelitian & \\
\hline
\end{tabular}

\subsection{Sosialisasi}

Sosialisasi diartikan sebagai setiap aktivitas yang ditujukan untuk memberitahukan, membujuk atau mempengaruhi masyarakat untuk memanfaatkan hal yang ditawarkan.

\subsection{Penyuluhan / pelatihan}

Peserta yang diikutkan dalam pelatihan ini sebanyak 20 orang yang terditi atas: anggota kelompok usaha tani mitra 10 orang, utusan dari masyarakat setempat sebanyak 5 orang, dan utusan lembaga adat dan penyuluh pertanian lapangan (PPL) sebanyak 5 orang, sehingga jumlah keseluruhan peserta adalah 20 orang.

\subsection{Kerja praktek / rancang bangun teknologi pertanian}

Kerja praktek dimaksudkan untuk memberikan ketrampilan kepada peserta terhadap teknologi yang didiseminasikan. Praktek diawali dengan pengumpulan bahan dan peralatan yang digunakan, kemudian dilakukan pembuatan ekstrak $N$. oleander menggunakan pelarut air. Pada kerja praktek diarahkan pada teknik menentukan komposisi bahan yang benar untuk menghasilkan ekstrak yang sesuai dengan yang diharapkan. Selanjutnya dilakukan pengaplikasian pada tanaman sayuran yang terserang hama.

\subsection{Pendampingan}

Dilakukan untuk memastikan bahwa teknologi yang disampaikan kepada peserta dapat dilaksanakan dengan baik sehingga hasil yang 
diperoleh dapat mencapai sasaran yaitu tersedianya ekstrak $N$. oleander yang dapat digunakan sebagai pestisida botani.

\section{HASIL DAN PEMBAHASAN}

\section{Sosialisasi}

Kegiatan sosialisasi dihadiri sebanyak 20 orang yang terdiri dari aparat desa, karang taruna dan masyarakat masyarakat setempat serta utusan lembaga adat dan penyuluh pertanian lapangan (Gambar 2). Kegiatan sosialisasi diawali dengan pretest mengenai penggunaan ekstrak tumbuhan sebagai pestisida nabati, pembagian handout, penyampaian materi sosialisasi, tanya jawab dan diakhiri dengan post test. Materi yang disampaikan adalah: Pentingnya pengendalian hama dan penyakit dengan pendekatan pengendalian hama terpadu, dan pemanfaatan pestisida biorasional dalam pengendalian hama.
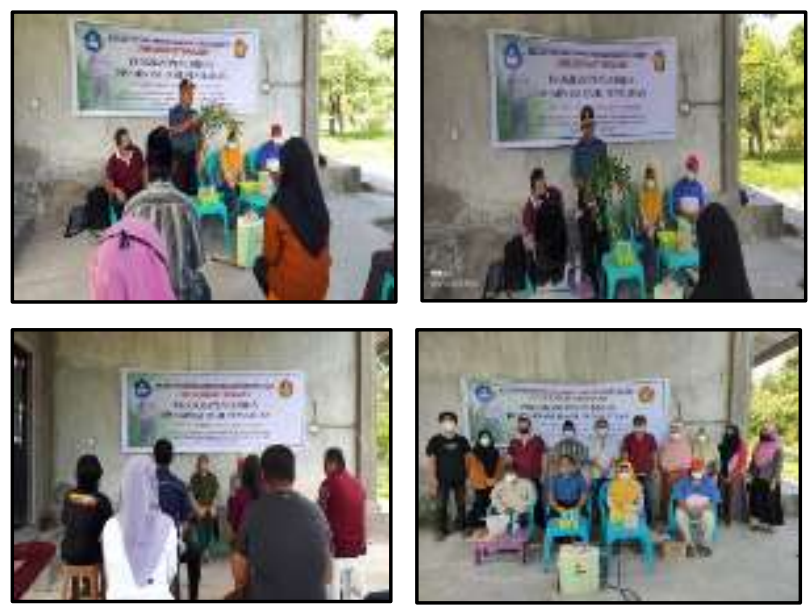

Gambar 2. Suasana saat pelaksanaan sosialisasi

Hasil sosialisasi menunjukkan bahwa masyarakat sudah sering mendengar tentang penggunaan ekstrak tumbuhan sebagai pestisida botani / nabati namun belum dilaksanakan dalam kegiatan usaha taninya. Hal tersebut karena peserta belum meyakini bahwa ekstrak tumbuhan dapat mengendalikan OPT. Selain itu peserta juga belum mengetahui cara memperoleh ekstrak tumbuhan yang dapat digunakan sebagai bahan pengendali. Setelah kegiatan sosialisasi peserta mulai tertarik karena dalam membuat ekstrak tumbuhan tidak sesulit dengan yang dibayangkan sebelum pelaksanaan sosialisasi.

Larutan ekstrak tumbuhan dapat dibuat dengan dengan cara diblender atau ditumbuk sampai menjadi halus. Selanjutnya direndam dalam air selama 24 jam kemudian disaring. Hasil saringan diperoleh ekstrak yang dapat disimpan untuk dijadikan sebagai pestisida botani / nabati

\section{Penyuluhan / pelatihan dan praktek rancang-bangun teknologi}

Penyuluhan yang diberikan meliputi dampak penggunaan pestisida kimia secara berlebihan, pengenalan pestisida nabati, pemanfaatan ekstrak tumbuhan sebagai pestisida nabati, cara ekstraksi bahan tumbuhan, teknik ektraksi $N$. oleander dan teknik aplikasinya sebagai bahan pengendali hama. Materi pelatihan tersebut disesuaikan dengan minat dan kebutuhan masyarakat supaya dapat termotivasi untuk mengikuti kegiatan dengan baik, sesuai dengan tujuan pelatihan yaitu meningkatkan motivasi peserta (Eldyani \& Wardoyo, 2018), meningkatkan pengetahuan dan ketarampilan yang mungkin juga meliputi perubahan sikap sehingga dapat melakukan pekerjaan lebih efektif (Kaswan, 2013). Setelah diberikan penyuluhan, selanjutnya dilakukan praktek pembuatan ekstrak.

Pembuatan ekstrak daun $N$. oleander mengacu pada Nasir et al. (2020), yaitu dengan terlebih dahulu mengambil daun $N$. oleander dari pohonnya kemudian dibersihkan dan selanjutnya dipotong menjadi bagian yang kecil. Selanjutnya dikeringkan dalam oven (pada suhu $40^{\circ} \mathrm{C}$ selama 1 x 24 jam). Daun yang sudah kering oven diblender sampai menjadi serbuk dan diayak untuk mendapatkan serbuk halus. Serbuk ditimbang sebanyak 31,25 g kemudian direndam menggunakan pelarut air sebanyak 1 liter selama 2 x 24 jam sambil dishaker (Gambar 3). Hasil rendaman disaring menggunakan kain kasa sampai diperoleh ekstrak $N$. oleander. Ekstrak yang diperoleh selanjutnya siap diencerkan bersama pelarut air dengan berbagai konsentrasi yang diinginkan untuk digunakan sebagai bahan pengendali OPT. 
Pada pelatihan teknik aplikasi ekstrak daun $N$. oleander, peserta dilatih untuk membuat konsentrasi / dosis larutan ekstrak dengan beberapa seri konsentrasi yaitu $5 \%, 10 \%, 15 \%$, dan $20 \%$. Selanjutnya diaplikasikan ke demplot pertanaman sayuran yang telah dipersiapkan sebelumnya. Dengan pelatihan tersebut peserta memiliki ketrampilan dalam menentukan konsentrasi dan teknik aplikasi esktrak daun $N$. oleander sebagai pestisida botani / nabati.

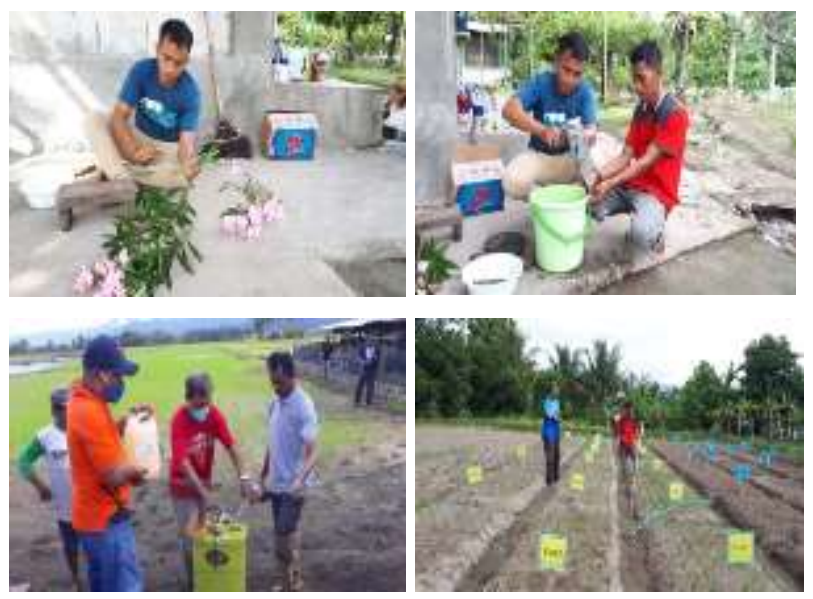

Gambar 3. Dokumen proses pembuatan ekstrak dan teknik aplikasi ekstrak tumbuhan Nerium oleander pada demplot pertanaman sayuran.

\section{Pendampingan}

Pendampingan merupakan kegiatan pembinaan yang dilakukan secara berkala dan berkelanjutan mengenai aplikasi teknologi dalam praktek langsung pada tingkat masyarakat. Dokumen pendampingan tampak pada Gambar 4. Kegiatan tersebut dilaksanakan setelah peserta telah diyakini memahami materi yang diberikan, selanjutnya dilakukan pemantapan dengan pendampingan berkelanjutan. Dengan pendampingan diharapkan dapat memperbaiki sikap, perilaku, keterampilan dan kesadaran kelompok mitra dalam mengelola agribisnisnya dengan tetap memperhatikan kelangsungan ekosistem untuk generasi sekarang dan mendatang dalam rangka mewujudkan pembangunan pertanian yang menguntungkan dan berwawasan lingkungan.
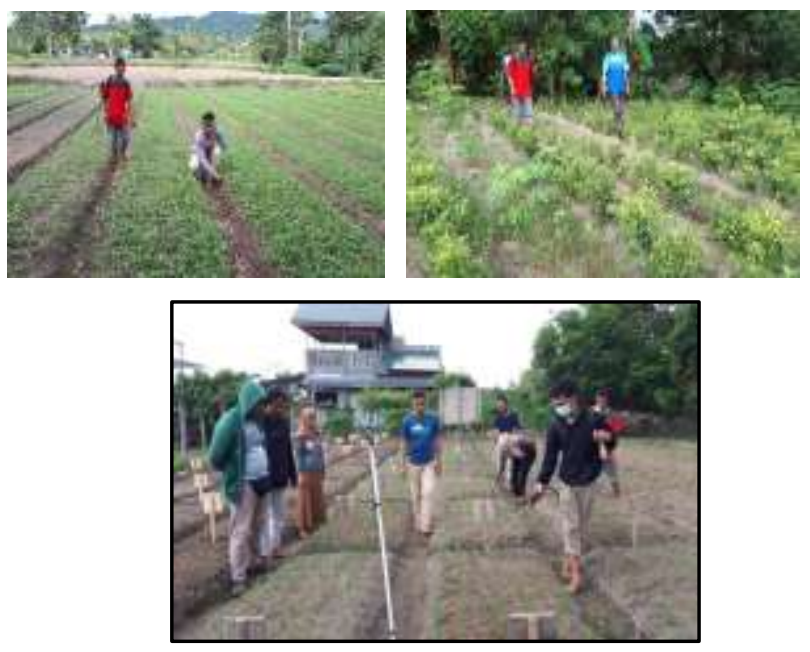

Gambar 4. Dokumentasi pelaksanaan pendampingan masyarakat

Berdasarkan hasil pengamatan yang dilakukan selama kegiatan pengabdian pada areal demplot aplikasi ekstrak daun $N$. oleander memperlihatkan bahwa semakin tinggi konsentrasi $N$. oleander yang digunakan maka intensitas serangan hama semakin rendah. Hal tersebut diduga disebabkan oleh kandungan bahan aktif dari N.oleander yang mengandung glycosida berupa senyawa oleandrin yang sangat mempengaruhi perkembangan hidup larva, yaitu bersifat toksik dan anti hormonal (Idris, 2014). Gangguan hormonal tersebut terlihat dari beberapa indikasi visual antara lain aktivitas pergerakan menjadi lambat bahkan cenderung lumpuh. Intensitas serangan yang rendah juga karena $N$. oleander bersifat antifeedant, insektisida, dan ovisidal (Osabutey et al., 2018; Utami \& Damanhuri, 2020).

Pestisida botani merupakan produk alam yang berasal dari tumbuhan yang mengandung bioaktif seperti alkaloid senyawa sekunder yang jika diaplikasikan ke hama sasaran, dapat mempengaruhi sistem syaraf, terganggunya sistem reproduksi, keseimbangan hormon, perilaku berupa penarik atau pemikat, penolak, mengurangi nafsu makan dan terganggunya sistem pernafasan (Hidayat, 2011).

Penggunaan $N$. oleander sebagai insektisida botani untuk pengendalian hama pada pertanaman sayuran dapat menjadi salah satu pertimbangan 
untuk diterapkan sebagai alternatif pengganti insektisida kimia sintetis karena ekstrak daun $N$. oleander dapat menekan intensitas serangan hama dan potensi sumberdaya tersebut banyak ditemukan sebagai tanaman hias di pekarangan rumah maupun di pinggir jalan.

\section{KESIMPULAN}

1. Pelaksanaan pengabdian diseminasi hasil penelitian tentang penggunaan ekstrak daun tumbuhan $N$. oleander sebagai insektisida botani kepada petani sayuran di Desa Sidera Trans memperoleh respon yang tinggi ditandai dengan kehadiran peserta pada setiap kegiatan.

2. Peserta dapat membuat ekstrak daun tumbuhan $N$. oleander, menentukan dosis dan konsentrasi yang akan diaplikasikan ke lahan usaha taninya.

3. Penggunaan ekstrak daun tumbuhan $N$. oleander sebagai pestisida botani menjadi alternatif bagi peserta / petani dalam melakukan pengendalian hama yang selama ini selalu mengandalkan penggunaan insektisida kimia. Hal tersebut dapat mengurangi biaya operasional usaha taninya sehingga penghasilannya diharapkan dapat meningkat

\section{UCAPAN TERIMA KASIH}

Dibiayai oleh Daftar Isian Pelaksanaan Anggaran (DIPA) Fakultas, Pascasarjana, PSDKU Tojo Una-una dan Universitas, Kementerian Pendidikan dan Kebudayaan Universitas Tadulako Sesuai dengan Surat Keputusan Rektor Universitas Tadulako Nomor: 3013/UN28/KP/2021, tanggal 23 April 2021.

\section{REFERENSI}

Ahmad, M., Farid, A. \& Saeed, M. (2018). Resistance to new insecticides and their synergism in Spodoptera exigua (Lepidoptera: $\quad$ Noctuidae) from Pakistan. Crop Protection 107:79-86. https://doi.org/10.1016/j.cropro.2017.12.02 $\underline{8}$
Astuti, U.P., Wahyuni, T., \& Honorita, B. (2013). Pembuatan pestisida nabati. Mendukung pengembangan Kawasan Rumah Pangan Lestari di Provinsi Bengkulu. Balai Pengkajian Teknologi Pertanian (BPTP) Bengkulu. 75 hal.

BPS Kecamatan Sigi Biromaru Dalam Angka, (2017). Jumlah penduduk dan rata-rata penduduk per rumah tangga Kecamatan Sigi Biromaru Dalam Angka 2016. BPS Kecamatan Sigi Biromaru Dalam Angka, 2017.

Eldyani, P., \& Wardoyo, P.. (2018). Upaya peningkatan kompetensi: dampak pelatihan bersubsidi serta peran instruktur. Jurnal Riset Ekonomi dan Bisnis, 142-153. https://doi.org/10.26623/jreb.v11i2.1082.

Hidayat, A. (2011). Metode Pengendalian Hama. Proyek Pengembangan Sistem dan Standar Pengelolaan SMK Direktorat Pendidikan Menengah Kejuruan, Jakarta.

Idris, H. (2014). Formula insektisida nabati untuk mengendalikan hama penggulung daun (Pachyzancla stultalis) pada tanaman nilam. Balai Penelitian Tanaman Rempah dan Obat, Bul. Littro, $25: 1$.

Kaswan (2013). Pelatihan dan Pengembangan Untuk Meningkatkan Kinerja SDM. Bandung: Penerbit Alfabeta.

Nasir, B., Toana, M.H., Lasmini, S.A., \& Parabowo, N. (2020). Efektivitas ekstrak Nerium oleander Linn. terhadap Spodoptera exigua Hubner. pada tanaman bawang merah yang diberi mulsa jerami padi di lahan kering. Prosiding Seminar Nasional Pertanian VII. Pola Pertanian Lahan Kering Berkelanjutan, 63-72.

Osabutey, A. F., Eziah, V., Buxton, T., \& Owusu, E. O. (2018). Evaluating the Insecticidal Potential of Aqueous Plant Extracts from Zanthoxylum zanthoxyloides and Anacardium occidentale against insect pest complexes of cabbage in an open field experiment. international Journal of 
Agricultural Science Research, 73(3), 1823.

Utami, K. A. S., \& Damanhuri, F. (2020). Pengaruh insektisida campuran daun kenikir (Cosmos caudatus) dan serai wangi (Cymbopogon nardus) terhadap hama kutu kebul (Bemisia tabaci Genn.) pada budidaya tanaman kedelai edamame. Agriprima, Journal of Applied Agricultural Sciences, 4(1),26-33.

Wahyudi, A. (2010). Nerium oleander pestisida botani untuk pengendalian hama. Warta Litbang Tanam 16 (2).
Wang, X., Xing, X., Yu, H., Liu, S., Yin, Y., Cui, P., Wu, Y., Yang, J., Jiang, C., \& Yang, Q. (2018). Monitoring and biochemical characterization of beta-cypermethrin resistance in Spodoptera exigua (Lepidoptera: Noctuidae) in Sichuan Province, China. Pesticide Biochemistry and Physiology 146: 71-79.

https://doi.org/10.1016/j.pestbp.2018.02.00 8 